\title{
Camptothecin-psammaplin A hybrids as topoisomerase I and HDAC dual-action inhibitors
}

\author{
Raffaella Cincinelli $^{ \pm a}$, Loana Musso $^{ \pm a}$, Roberto Artali ${ }^{b}$, Mario Guglielmi $^{c}$, Erminia Bianchino $^{\mathrm{c}}$, \\ Francesco Cardile $^{\mathrm{c}}$, Fabiana Colellic $^{\mathrm{c}}$, Claudio Pisano ${ }^{\mathrm{c}}$, Sabrina Dallavalle $^{\mathrm{a}^{*}}$
}

${ }^{a}$ Department of Food, Environmental and Nutritional Sciences, Division of Chemistry and Molecular Biology, Università degli Studi di Milano, via Celoria 2, 20133 Milan, Italy.

${ }^{b}$ Scientia Advice, di Roberto Artali, 20832 Desio (MB), Italy

${ }^{c}$ Biogem, Research Institute, Ariano Irpino (AV), Italy

${ }^{ \pm}$Equal contribution

* Corresponding author. E-mail address: sabrina.dallavalle@unimi.it (S. Dallavalle).

\begin{abstract}
Recent studies have demonstrated enhanced anticancer effects of combination therapy consisting of camptothecin derivatives and HDAC inhibitors. To exploit this synergy in a single active compound, we designed new dual-acting multivalent molecules simultaneously targeting topoisomerase I and HDAC. In particular, a selected compound containing a camptothecin and the psammaplin A scaffold showed a broad spectrum of antiproliferative activity, with IC $_{50}$ values in the nanomolar range. Preliminary in vivo results indicated a strong antitumor activity on human mesothelioma primary cell line MM487 orthotopically xenografted in CD-1 nude mice and very high tolerability.

\section{Introduction}

The epigenetic control of chromatin organization by the covalent modification of DNA and histone proteins plays a major role in the regulation of cell differentiation, proliferation and survival. Several human diseases such as cancers, neurodegenerative diseases or metabolic disorders result from abnormal gene expression due to the disequilibrium between epigenetic enzymes activities. Histone N-3-lysine acetylation was identified as a key player, a reaction controlled by histone acetyl transferases (HAT) in balance with histone deacetylases (HDAC).
\end{abstract}

Keywords: Psammaplin; HDAC inhibitors; camptothecin; antiproliferative activity; antitumor activity; dual-action inhibitors. 
In recent years, HDAC inhibitors have emerged as highly attractive targets for anticancer therapies for their overexpression in several cancer cell lines, resulting in tumor suppressor gene silencing [1, 2].

Among the myriad of HDAC inhibitors, the cytotoxic marine natural product psammaplin A (1) from the sponge Pseudoceratina sp. [3-5] has gained interest due to its structure, and potent HDAC and DNA methyltransferase inhibition [6].

Psammaplin A displays an intriguing structure, being a symmetrical disulfide with a cystamine linker functionalized on both sides by $\alpha$-(hydroxyimino)acyl moieties (Chart 1). It functions as a natural prodrug, requiring reduction of its disulfide functionality to the corresponding thiol monomer in order to potently inhibit HDACs [7].

Since the initial report by Crews and co-workers on psammaplin A as a potent HDAC inhibitor, crystal structures of analogues have been obtained in order to perform SAR studies on various epigenetic targets [8]. These studies showed that both the disulfide bridge and the $\alpha$ hydroxyiminoamide moieties are necessary for HDAC inhibition, whereas structural variations on the aromatic ring are allowed [9].

During the last years we have been involved in the development of hybrid bifunctional agents. Hybrid agents are compounds designed to inhibit simultaneously multiple cellular targets relevant to tumour growth/survival. The interest toward multivalent ligand design is rapidly increasing, due to the potential advantages of such bifunctional molecules [10]. The benefits of drugs with multiple targets include the improvement of the efficacy by exploiting synergistic interactions, the enhancement of the selectivity resulting in a better tolerability and modulation of drug resistance [11]. Additionally, multivalent molecules are expected to provide pharmacokinetic and pharmacodynamic advantages over the separate administration of the two drug components.

Specifically, we were interested in developing bifunctional compounds containing the camptothecin scaffold [12]. Camptothecins are clinically validated topoisomerase I (Top1) inhibitors [13]. The parent compound camptothecin (CPT, chart 1) was isolated for the first time by Wall et al. [14] from the tree Camptotheca acuminata, a plant of the Nyssaceae family originating from China. Two semisynthetic CPT derivatives have been approved by US FDA for cancer chemotherapy, irinotecan (CPT-11) and topotecan. Belotecan has been approved in South Korea for treatment of NSCLC. (Figure 1). Other derivatives are in different steps of clinical development, such as NSC603071 (9-amino-camptothecin), 9-CN or 9-nitrocamptothecin, GG-211 (GI 147211), and DX8591f. Although the conventional CPT derivatives have made a significant contribution to cancer treatment, the dose-limiting toxicities and drug resistance remain significant hurdles in the use of these drugs. 


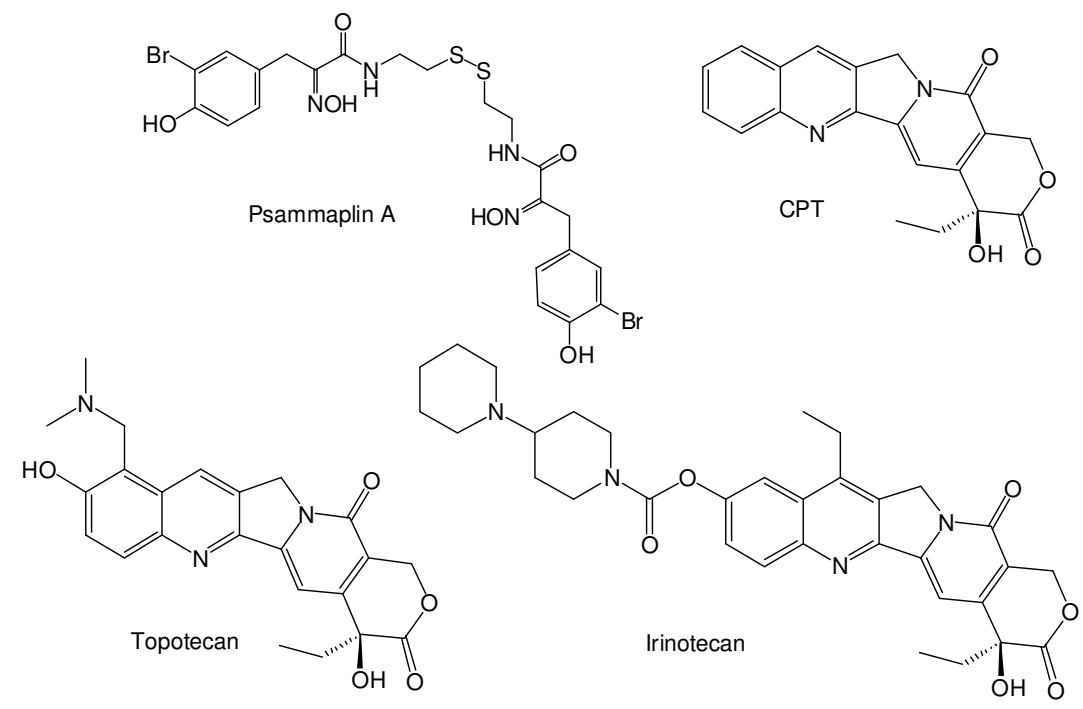

Chart 1. Structures of psammaplin A and camptothecin topoisomerase I inhibitors.

Recently, it has been reported that co-treatment with HDAC inhibitors and camptothecin derivatives (such as topotecan or irinotecan) synergistically block cell proliferation [15-20]. To exploit this synergy in a single active compound, we designed new dual-acting multivalent molecules containing a camptothecin and the psammaplin A scaffold. There are examples in the literature of dual-acting molecules containing camptothecin and SAHA-like templates [21]. However, to the best of our knowledge, the conjugation of a psammaplin to a CPT has not been attempted before. The following criteria have guided the design of the conjugates: a) a CPT moiety substituted in a suitable position to maintain cytotoxic activity; b) a proper linker between the psammaplin A pharmacophore and the CPT skeleton. In previous works we have reported that CPT functionalization at C-7 is highly tolerable [22-24]. Particularly, we have synthesized 7oxyiminomethyl derivatives showing potent in vitro and in vivo activity, even when bulky and long-chain substituents were introduced [22, 24]. For this reason, suitably substituted (E)-7oxyminomethyl CPTs were selected for conjugation to the psammaplin A active fragment through an amide bond (Figure 1). The ability of the compounds to act as both HDAC and Topoisomerase-I ligands was studied by molecular modeling. The choice of the spacer length $(n=5$, Figure 1$)$ was based on a preliminary virtual screening study in which all compounds with $\mathrm{n}$ ranged from 1 to 10 were taken into account. The results obtained prompted us to select compounds 1a-c for topoisomerase I - HDAC dual inhibitory activity investigation. 


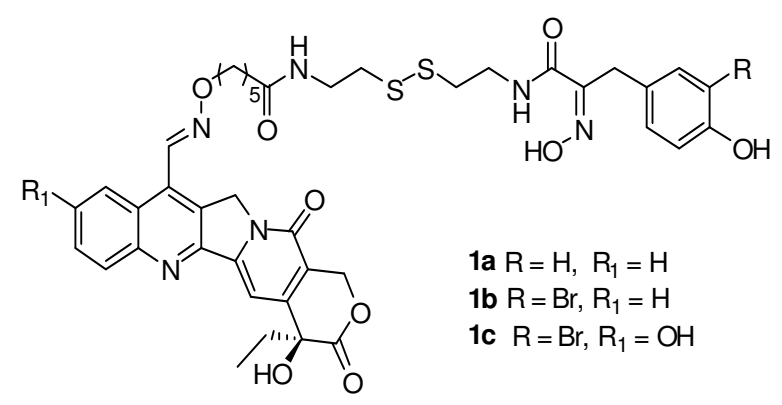

Fig. 1. Structure of hybrids CPT-psammaplin A 1a-c.

\section{Results and discussion}

\subsection{Chemistry}

The reaction of 7-(dimethoxymethyl)-camptothecin 2a [25] with 6-aminooxyhexanoic acid hydrobromide [26] in acetic acid afforded compound 3a in 73\% yield (Scheme 1). Following a similar procedure, compound $\mathbf{3 b}$ was obtained starting from 10-hydroxy-7-formylcamptothecin $\mathbf{2 b}$ [27]. The choice of synthesizing a 10-hydroxyderivative starting from $\mathbf{2 b}$ is based on the presence of this structural feature in both the CPT derivatives in clinical use, topotecan and irinotecan.

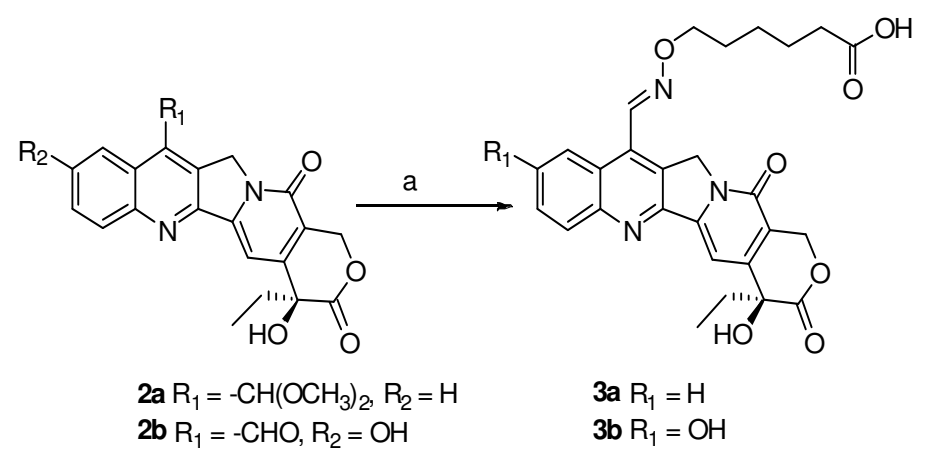

Scheme 1. Synthesis of camptothecin derivatives 3a-b. Reagents and conditions: a) for 3a: 6-aminooxyhexanoic acid hydrobromide, acetic acid, $3 \mathrm{~h}, 80{ }^{\circ} \mathrm{C}, 73 \%$; for $\mathbf{3 b}$ : ethanol, pyridine, $4 \mathrm{~h}$, reflux, $75 \%$.

The synthesis of camptothecin - psammaplin A hybrid compounds (1a-c) is described in Scheme 2. Compound 4a was synthesized in two steps from the commercially available 4hydroxyphenylpyruvic acid [28]. Following a procedure reported in the literature [29], compound 4a was brominated with $\mathrm{KBr}$ and $\mathrm{KBrO}_{3}$ to give hydroxyiminopropionic acid $\mathbf{4 b}$. Condensation of acids 4a-b with Boc-protected cystamine $\mathbf{5}$ afforded the corresponding amides, which in turn were treated with trifluoroacetic acid in dichloromethane to yield the desired intermediates 6a-b. Condensation of the camptothecin derivative 3a with the psammaplin fragments $\mathbf{6 a - b}$ by WSC and HOBt, afforded the hybrids $\mathbf{1 a}$ and $\mathbf{1 b}$ in $74 \%$ and $89 \%$ yield, respectively. The $10-\mathrm{OH}$ derivative $\mathbf{3 b}$ was condensed with the amine $\mathbf{6 a}$ to give the hybrid $\mathbf{1 c}$ in $57 \%$ yield. 


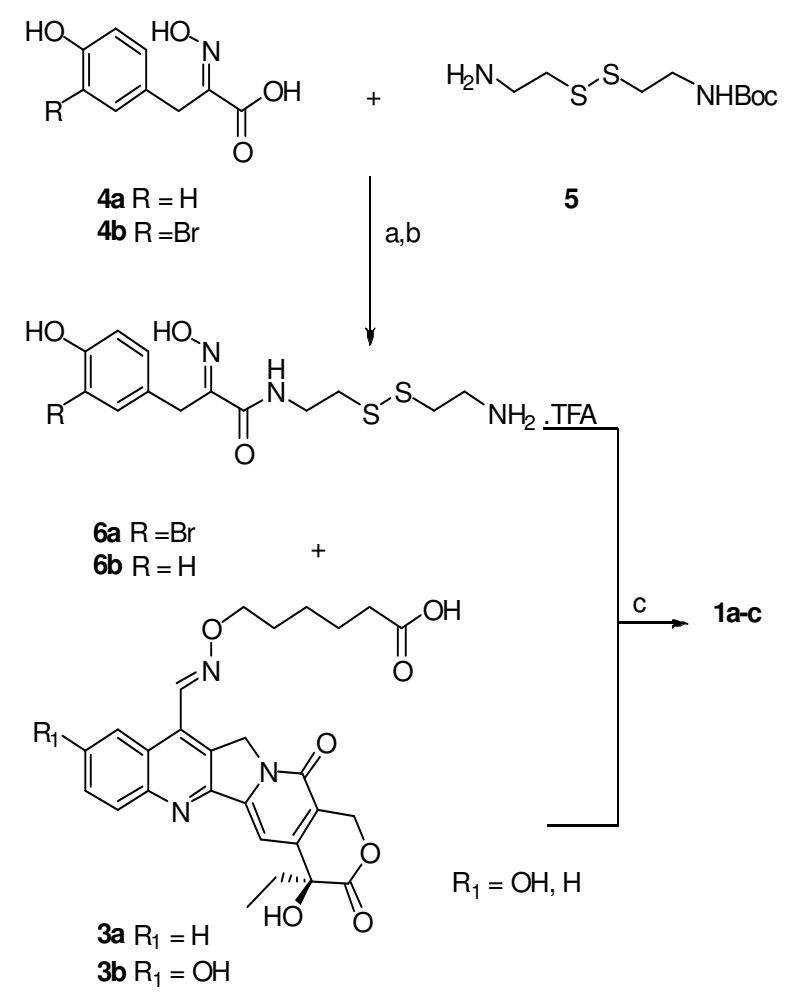

Scheme 2. Synthesis of CPT- psammaplin hybrids 1a-c. Reagents and conditions: a) NHS, DCC, DMF, 24h; b) TFA, $\mathrm{CH}_{2} \mathrm{Cl}_{2}, 1 \mathrm{~h}$; c) i: WSC, HOBt, DMF, 3-24h, rt; ii: 6a or 6b, 2-3 h, rt, 1a: 74\%, 1b: 89\%, 1c: $57 \%$.

\subsection{Molecular Modeling Studies}

It has been previously reported that in terms of its HDAC activity, psammaplin A functions as a natural prodrug, the active free thiol being revealed following disulfide reduction upon cell uptake $[30,31]$. Thus, the proposed binding models take into account the reduction of the disulfide bridge in cell cultures, resulting in the release of reduced psammaplin and CPT fragments.

DNA-Topoisomerase-I complexes. Molecular modeling studies were performed to explore the binding mode for the CPT fragment released from compounds 1a-b and the 10-OH CPR fragment released from compound 1c to the DNA-topoisomerase-I complex. The two fragments are properly positioned inside the intercalation binding site, created by conformational changes of the phosphodiester bond between the +1 (upstream) and -1 (downstream) base pairs of the uncleaved strand, which effectively "open" the DNA duplex, with multiple strong $\pi$ - $\pi$ stacking interactions between the aromatic A-D rings of the fragments and both the -1 and +1 base pairs. Compounds show a hydrogen bond between the nitrogen atom of ring B and R364 residue, which in turn forms an additional hydrogen bond with the $\mathrm{OH}$ group of the lactone ring $\mathrm{E}$. The lactone ring is also involved in another hydrogen bond with the $\mathrm{OH}$ group of the lactone ring E and D533. 
Table 1. Binding free energies (kcal/mol) and distances (in $\AA$ ) between the two CPT-fragments and the binding site residues of the DNA-topoisomerase-I system.

\begin{tabular}{|c|c|c|c|c|c|c|}
\hline & $\Delta G_{\text {binding }}$ & $\mathrm{D}^{533} \mathrm{O}_{\delta 2}$ & $\mathrm{R}^{364} \mathrm{~N}_{2}$ & $\mathrm{E}^{356} \mathrm{O} \varepsilon_{2}$ & $\mathrm{~K}^{436} \mathrm{~N}_{\zeta}$ & $\mathrm{DA}^{113} \mathrm{~N}_{6}$ \\
\hline $\begin{array}{c}\text { CPT- } \\
\text { fragment } \\
10 \mathrm{OH}\end{array}$ & -12.51 & 2.61 & $3.03-2.74$ & - & 2.97 & - \\
\hline $\begin{array}{c}\text { CPT- } \\
\text { fragment }\end{array}$ & -13.29 & 2.55 & $3.30-2.88$ & 2.56 & 3.05 & 3.30 \\
\hline
\end{tabular}

The interaction pattern of the 10-OH CPT fragment within the binding site is completed by a hydrogen bond between the phenolic $\mathrm{OH}$ and E356, an interaction clearly impossible for the other CPT fragment. The side chain of both CPT derivatives is located in the rear region of the binding site, resting on the DNA duplex and forming a series of interactions that contribute to the stability of the complexes. In both complexes, the lateral chain is arranged to form a hydrogen bond between the amidic $\mathrm{C}=\mathrm{O}$ group and $\mathrm{K} 436 \mathrm{~N}$. Moreover, in the phenolic derivative, the lateral chain shows a slight twist that allows for the formation of a hydrogen bond between the oxime nitrogen and DA113N6. The 3D structures of the complexes with the DNA-Topoisomerase-I system are given in Figure 2.

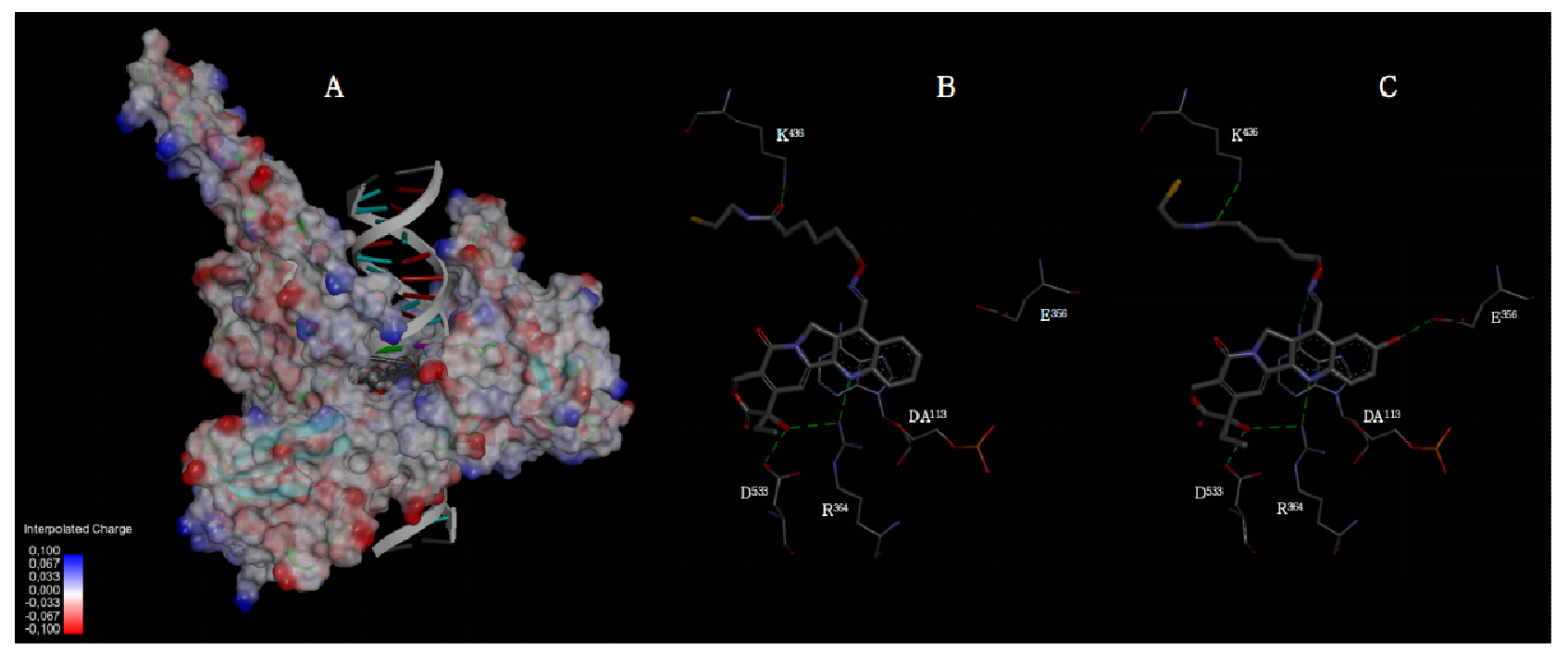

Fig. 2. (A) - Schematic representation of the proposed top-score binding mode for the CPT fragments in the DNATopoisomarase-I complex. Topoisomerase-I is represented as Solvent Accessible Surface (SAS) coded by interpolated charges, while the ligand is rendered in CPK. (B,C) - Top-score conformations of the two CPT fragment complexes, with the aminoacid/nucleotide side chains relevant to the discussion rendered in line and the ligands in stick. Hydrogen bonds are shown as green dotted lines. 


\section{HDAC-II complexes.}

The complexes are obtained by molecular docking of psammaplin fragments from compounds 1a-c using the Class I Rpd3-like protein HDAC2 as a model.

The analysis of the complexes obtained by molecular docking shows the key interactions of these moieties with the enzyme. The free thiol group forms a $\mathrm{H}$-bond (2.45 ) with $\mathrm{H}^{146} \mathrm{H}_{\varepsilon 2}$ and chelates the $\mathrm{Zn}^{2+}$ ion, while the oxime group forms a hydrogen bond (2.30^) with $\mathrm{D}^{104} \mathrm{O}_{\delta 2}$ (see Figure 3), and the 4-hydroxyphenyl group gives few hydrophobic contacts with $\mathrm{Y}^{209}, \mathrm{~F}^{155}$ and $\mathrm{F}^{210}$ belonging to the entrance of the binding site.

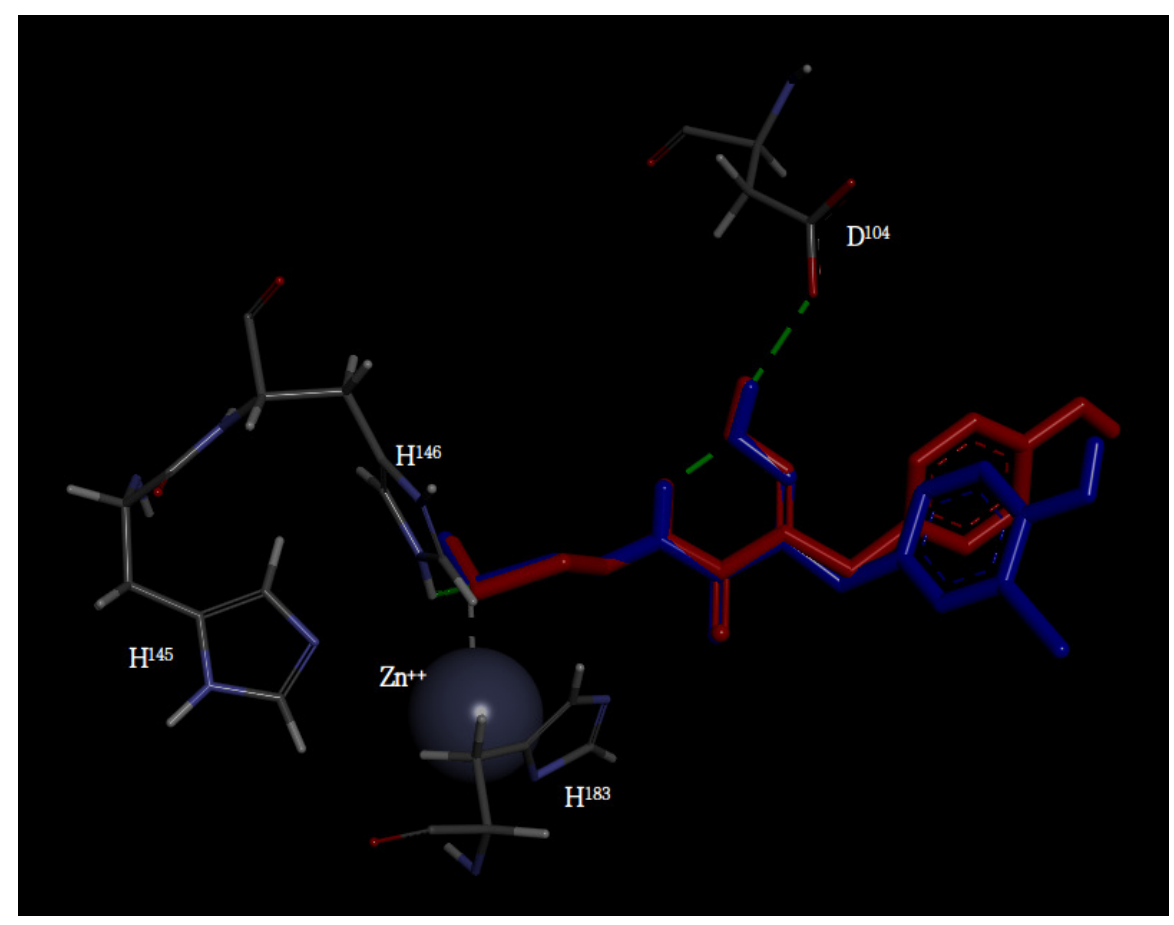

Fig. 3. Top-score conformations of the of reduced psammaplin A fragment (in blue) and bromine-free analogue (in red) complexes to HDAC-II model (5IWG). The aminoacids side chains relevant to the discussion are rendered in line and the ligands in stick. Hydrogen bonds are shown as green dotted lines. The zinc ion is shown in CPK.

\subsection{Biological activity}

The antiproliferative activity was evaluated on a series of human solid tumor cell lines (NCI-H460: non small cell lung cancer; CAPAN 1: human pancreatic ductal adenocarcinoma; A431: human epidermoid carcinoma; HeLa: human epithelioid cervix carcinoma; HT29: human colon adenocarcinoma; DU145: human prostate cancer; HepG2: liver hepatocellular carcinoma; A2780: human ovarian carcinoma; A2780-Dox: doxorubicin-resistant human ovarian carcinoma. The 
activity was assessed after $72 \mathrm{~h}$ with the SRB assay. Irinotecan, SAHA and trichostatin a were used as reference standards.

Compounds 1a-b showed significant antiproliferative activity in the nanomolar range $(0.05 \mu \mathrm{M}<$ $\left.\mathrm{IC}_{50}<0.8 \mu \mathrm{M}\right)$, while SAHA $\left(\mathrm{IC}_{50}>0.9 \mu \mathrm{M}\right)$ and irinotecan $\left(\mathrm{IC}_{50}>1.5 \mu \mathrm{M}\right)$ were less effective (Table 3). The introduction of the hydroxy group on the CPT scaffold (compound 1c) had a deleterious effect, causing a reduction of the activity on H460 and CAPAN1 cell lines. The removal of the bromine atom in the psammaplin A pharmacophore did not cause any significant change in activity (1a vs $\mathbf{1 b}$ ). Interestingly, compound $\mathbf{1 b}$ seemed to be poorly affected by the multidrugresistant protein PGP, as showed in Table 3 by comparing the $\mathrm{IC}_{50}$ against $\mathrm{A} 2780$ with respect to resistant A2780-Dox (RI: 3.8).

Thus, $\mathbf{1 b}$ was selected for further investigation. The compound was very effective against a number of hematologic cancer cell lines (DG-75 Burkitt lymphoma; MAVER, MINO, JECO-1 mantle cell lymphoma; KM-H2 and L-428 Hodgkin lymphoma, OCI-LY3 and U-2932 diffuse large B-cell lymphoma, NB4 acute promyelocytic leukemia). Indeed, 1b showed a cytotoxic potency mostly in the nanomolar range $\left(0.03 \mu \mathrm{M}<\mathrm{IC}_{50}<0.6 \mu \mathrm{M}\right)$ and greater than SAHA and irinotecan except for DG-75 cell line (Table 4).

Table 3. Human solid tumor cell lines exposed to Top1, HDAC and dual Top1 / HDAC inhibitors.

\begin{tabular}{llllll}
\hline Compound & Irinotecan & SAHA & 1a & 1b & 1c \\
\hline Cell lines & & & IC50 \pm SD $(\boldsymbol{\mu M})^{\mathrm{a}}$ & \\
\hline NCI-H460 & $2.4 \pm 0.1$ & $1.0 \pm 0.1$ & $0.22 \pm 0.005$ & $0.17 \pm 0.006$ & $0.88 \pm 0.003$ \\
CAPAN1 & $1.5 \pm 0.1$ & $1.8 \pm 0.2$ & $0.075 \pm 0.005$ & $0.05 \pm 0.002$ & $0.2 \pm 0.01$ \\
A431 & $4.1 \pm 0.1$ & $3.5 \pm 0.1$ & $0.31 \pm 0.04$ & $0.18 \pm 0.02$ & N.e. \\
HeLa & $5.8 \pm 0.6$ & $2.7 \pm 0.2$ & $0.58 \pm 0.2$ & $0.47 \pm 0.1$ & N.e. \\
HT29 & $4.8 \pm 0.4$ & $2.2 \pm 0.3$ & $0.46 \pm 0.1$ & $0.66 \pm 0.2$ & N.e. \\
DU145 & $2.8 \pm 0.07$ & $0.87 \pm 0.03$ & $0.19 \pm 0.01$ & $0.11 \pm 0.01$ & N.e. \\
HepG2 & $4.0 \pm 0.8$ & $1.54 \pm 0.1$ & $0.61 \pm 0.2$ & $0.76 \pm 0.2$ & N.e. \\
A2780 & $3.8 \pm 0.5$ & $2.1 \pm 0.2$ & $0.29 \pm 0.03$ & $0.22 \pm 0.02$ & N.e. \\
A2780-Dox & $20.1 \pm 2.9$ & $3.3 \pm 0.6$ & $1.6 \pm 0.5$ & $0.83 \pm 0.2$ & N.e. \\
\hline
\end{tabular}




\begin{tabular}{lllll}
\hline RI & 5.3 & 1.6 & 5.5 & 3.8 \\
\hline
\end{tabular}

${ }^{\mathrm{a}}$ Antiproliferative activity assessed upon $72 \mathrm{~h}$ with the SBR assay. N.e. $=$ not evaluated.

Table 4. Human lymphoma and leukemic cell lines exposed to Top1, HDAC, and dual Topo1/HDAC inhibitor $\mathbf{1 b .}$

\begin{tabular}{|c|c|c|c|c|c|c|c|c|c|}
\hline & MINO & MAVER-2 & JECO-1 & U-2932 & OCI-LY3 & L-428 & KM-H2 & DG-75 & NB4 \\
\hline Cpd & \multicolumn{9}{|c|}{$\mathrm{IC}_{50} \pm \mathrm{SD}(\mu \mathrm{M})^{\mathrm{a}}$} \\
\hline Irinotecan & $>10(36 \%)$ & $0.74 \pm 0.1$ & $\begin{array}{l}>10 \\
(48 \%)\end{array}$ & $4.4 \pm 0.8$ & $\begin{array}{l}>10 \\
(0 \%)\end{array}$ & $\begin{array}{l}>10 \\
(0 \%)\end{array}$ & $\begin{array}{c}>10 \\
(12 \%)\end{array}$ & $\begin{array}{l}>10 \\
(0 \%)\end{array}$ & $1.0 \pm 0.3$ \\
\hline SAHA & $1.1 \pm 0.3$ & $1.8 \pm 0.2$ & $3.5 \pm 0.1$ & $2.7 \pm 0.2$ & $2.2 \pm 0.3$ & $\begin{array}{l}0.87 \pm \\
0.03\end{array}$ & $1.54 \pm 0.1$ & $2.1 \pm 0.2$ & $3.3 \pm 0.6$ \\
\hline $1 b$ & $\begin{array}{l}0.035 \pm \\
0.01\end{array}$ & $\begin{array}{l}0.3 \pm \\
0.09\end{array}$ & $\begin{array}{l}0.06 \pm \\
0.02\end{array}$ & $\begin{array}{l}0.11 \pm \\
0.03\end{array}$ & $\begin{array}{l}0.1 \pm \\
0.01\end{array}$ & $\begin{array}{l}0.6 \pm \\
0.09\end{array}$ & $\begin{array}{l}0.28 \pm \\
0.07\end{array}$ & $\begin{array}{l}8.4 \pm \\
0.4\end{array}$ & $\begin{array}{c}0.047 \pm \\
0.01\end{array}$ \\
\hline
\end{tabular}

${ }^{a}$ Human lymphoma cells were treated with Topo1, HDAC, and dual Topo1/HDAC inhibitors and the anti-proliferative activity assessed upon $72 \mathrm{~h}$ with the MTT assay.

Given the promising results, compound 1b was also tested against a series of human ex-vivo luciferase-transfected mesothelioma cell lines (MM432 sarcomatoid; MM473 hepitelioid; MM487 biphasic), showing a significant antiproliferative activity, higher than the reference compounds SAHA and irinotecan (Table 5).

Table 5. Human ex-vivo luciferase-transfected mesothelioma cell lines exposed to 1b dual Top1 / HDAC inhibitor.

\begin{tabular}{cccc}
\hline & MM432 & MM473 & MM487 \\
\hline Compound & \multicolumn{3}{c}{ IC $_{50} \pm \mathrm{SD}(\mu \mathrm{M})^{\mathrm{a}}$} \\
\hline 1b & $4.0 \pm 0.6$ & $1.9 \pm 0.5$ & $0.13 \pm 0.02$ \\
SAHA & $6.5 \pm 0.8$ & $8.2 \pm 0.6$ & $4.1 \pm 0.6$ \\
Irinotecan & $10.0 \pm 2.0$ & - & $9.4 \pm 0.7$
\end{tabular}

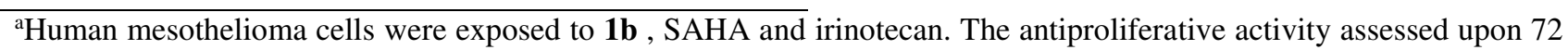
$\mathrm{h}$ with the SRB assay.

In terms of HDACs inhibition, the compound showed a significant activity against four purified HDAC isoforms, representative of class I (HDAC 1, 2) and Class IIb (HDAC 6, 10) HDACs, displaying optimal activity against HDAC10. Conversely, 1b was inactive against HDAC 4 
(representative of Class IIa HDACs), similarly to what reported for other psammaplin A analogues against Class IIa HDACs [29].

A similar profile of HDAC isoforms inhibition was found for compound 1c (Table 6).

Table 6. Inhibition of HDAC isoforms by compounds 1b and 1c. Trichostatin A and TMP269 were used as reference compounds.

\begin{tabular}{llllll}
\hline Compound & HDAC1 & HDAC2 & HDAC4 & HDAC6 & HDAC10 \\
\cline { 2 - 6 } & & \multicolumn{3}{c}{ IC $_{50}(\mathrm{M})$} \\
\hline 1b & $1.50 \mathrm{E}-07$ & $3.27 \mathrm{E}-07$ & n.a. & $7.09 \mathrm{E}-07$ & $7.55 \mathrm{E}-09$ \\
$\mathbf{1 c}$ & $2.53 \mathrm{E}-07$ & $4.10 \mathrm{E}-07$ & n.a. & $1.49 \mathrm{E}-06$ & $9.12 \mathrm{E}-09$ \\
Trichostatin A & $1.244 \mathrm{E}-08$ & $2.36 \mathrm{E}-08$ & - & $2.09 \mathrm{E}-09$ & $3.20 \mathrm{E}-08$ \\
TMP269 & - & - & $3.53 \mathrm{E}-07$ & - & - \\
\hline
\end{tabular}

$\mathrm{IC}_{50}$ values were calculated using the GraphPad Prism 4 program based on a sigmoidal dose-response equation (see SI). n.a. $=$ not active

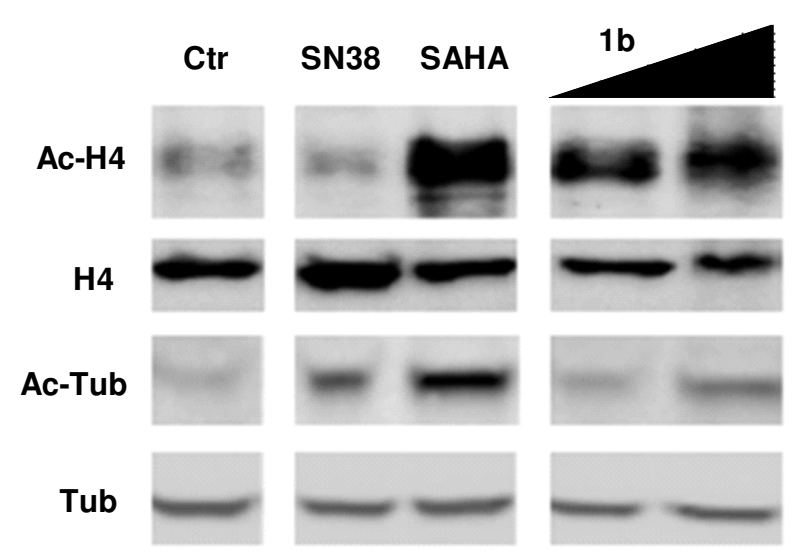

Fig. 4. MM473 cells were treated for $24 \mathrm{~h}$ with SN38 $(0.5 \mu \mathrm{M})$, SAHA $(1 \mu \mathrm{M})$ and with $1 \mathbf{b}(0.2$ and $0.5 \mu \mathrm{M})$. Cells were lysed in $0.5 \% \mathrm{NP}-40$ and $40 \mu \mathrm{g}$ of total proteins were loaded on NuPAGE $4-12 \%$ (Invitrogen), transferred to a nitrocellulose paper and probed with specific antibodies

To explore the HDAC inhibitory activity of compound $\mathbf{1 b}$ in the cells, accumulation of both acetylated histone $\mathrm{H} 4$ and acetylated tubulin was investigated in the treated cells using western blot analysis. The in vitro exposure of MM473 cells to $\mathbf{1 b}$ induced hyperacetylation of nuclear histone $\mathrm{H} 4$ protein, the substrate of $\mathrm{HDAC} 1 / 2$, but it did not hyperacetylate cytoplasmatic $\alpha$ tubulin, a substrate of HDAC6 (Figure 4). This result suggested that $\mathbf{1 b}$ has a preferential nuclear localization that could be relevant for the exploitation of the dual HDAC/Top1 mechanism, being Top1 a nuclear enzyme. 
Compound 1b was also tested on MM473 and MM487 cell lines to assess the effect on cell cycle progression and induction of apoptosis. FACS analysis revealed a steady block of treated-cells in S or $\mathrm{S}-\mathrm{G}_{2} \mathrm{M}$ phase. Moreover, an effective induction of apoptosis (sub- $\mathrm{G}_{0 / 1}$ population) was triggered by $\mathbf{1 b}$ on both tumor cell lines, with a higher effect on biphasic MM487 mesotelioma cell line (Tables 7,8).

Table 7. Flow cytometric evaluation of human tumor cell line MM473 exposed to $\mathbf{1 b}$

\begin{tabular}{|c|c|c|c|c|}
\hline $24 \mathrm{~h}$ & $\mathbf{G}_{0 / 1}(\%)$ & $\mathbf{S}(\%)$ & $\mathbf{G}_{2} / \mathbf{M}(\%)$ & Apo (\%) \\
\hline Control & 54.5 & 29.8 & 15.7 & 2.5 \\
\hline $1 b$ & 28.0 & 58.97 & 13.1 & 3.8 \\
\hline $48 \mathrm{~h}$ & G0/1 $(\%)$ & $\mathbf{S}(\%)$ & $\mathbf{G}_{2} / \mathbf{M}(\%)$ & Apo (\%) \\
\hline Control & 71.8 & 23.9 & 4.3 & 2.2 \\
\hline $1 \mathrm{~b}$ & 4.5 & 83.5 & 12.0 & 9.9 \\
\hline $72 \mathrm{~h}$ & $\mathbf{G}_{0 / 1}(\%)$ & $\mathbf{S}(\%)$ & $\mathbf{G}_{2} / \mathbf{M}(\%)$ & Apo (\%) \\
\hline Control & 80.2 & 15.1 & 4.6 & 1.4 \\
\hline $1 \mathrm{~b}$ & $6, .2$ & 79.3 & 14.5 & 11.0 \\
\hline \multicolumn{5}{|c|}{$\begin{array}{l}\text { Tumor cells were exposed for } 72 \mathrm{~h} \text { to test items }\left(2 \times \mathrm{IC}_{50}\right. \\
\text { cytometer. The CellQuest software was used to acqu } \\
\text { performed with the ModFit software. }\end{array}$} \\
\hline $24 \mathrm{~h}$ & $\mathbf{G}_{0 / 1}(\%)$ & $\mathbf{S}(\%)$ & $\mathbf{G}_{2} / \mathbf{M}(\%)$ & $\operatorname{Apo}(\%)$ \\
\hline Control & 57.9 & 25.2 & 16.9 & 0.5 \\
\hline $1 \mathrm{~b}$ & 20.6 & 77.62 & 1.8 & 2.6 \\
\hline $48 \mathrm{~h}$ & $\mathbf{G}_{0 / \mathbf{1}}(\%)$ & $\mathbf{S}(\%)$ & $\mathbf{G}_{2} / \mathbf{M}(\%)$ & Apo (\%) \\
\hline Control & 73.8 & 13.7 & 12.5 & 0.3 \\
\hline $1 b$ & 16.5 & 67.8 & 15.7 & 13.1 \\
\hline $72 \mathrm{~h}$ & G0/1 $(\%)$ & $\mathbf{S}(\%)$ & $\mathbf{G}_{2} / \mathbf{M}(\%)$ & Apo $(\%)$ \\
\hline Control & 80.0 & 14.6 & 5.4 & 0.6 \\
\hline $1 \mathrm{~b}$ & 19.6 & 59.2 & 21.2 & 25.4 \\
\hline
\end{tabular}

Tumor cells were exposed for $72 \mathrm{~h}$ to test items $\left(2 \mathrm{xIC}_{50}\right.$ dose, $\left.0.3 \mu \mathrm{M}\right)$, stained with PI, and processed on a FACScan flow cytometer. The CellQuest software was used to acquire data and assess apoptosis, while cell cycle analysis was performed with the ModFit software. 
The efficacy of the new dual inhibitor $\mathbf{1 b}$ was evaluated on human mesothelioma primary cell line MM473 orthotopically xenografted in CD-1 nude mice. After tumor injection and when the tumors were in growing phase (day 15 , from tumor injection), mice were intravenously treated with $\mathbf{1 b}$ (90 $\mathrm{mg} / \mathrm{kg}, \mathrm{q} 4 \mathrm{dx} 3 \mathrm{w})$, irinotecan $(20 \mathrm{mg} / \mathrm{kg}, \mathrm{q} 7 \mathrm{dx} 3)$ or vehicle as negative control. The tumor volume was measured as BLI signal and expressed as average radiance.

The molecule had a strong antitumor activity as shown in Figure 5 and summarized in Table 9. Additionally, the tumor chemioluminescence of animals treated with $\mathbf{1 b}$ indicated that the compound acted both by reducing the tumor growth progression and, in some cases, by reducing the tumor size until the disappearance of the bioluminescent signal. Interestingly, the antitumor activity was observed at well tolerated doses (no reduction in body weight was observed). Conversely, irinotecan administered at $20 \mathrm{mg} / \mathrm{kg}$ had only a marginal antitumor effect (not significant, $\mathrm{p}>0,5$ ).

Table 9. Antitumor activity of $\mathbf{1 b}$ compared to irinotecan on human mesothelioma tumor intrapleurally xenografted in nude mice

\begin{tabular}{|c|c|c|c|c|c|c|}
\hline $\begin{array}{l}\text { Tumor } \\
\text { cell line }\end{array}$ & $\begin{array}{c}\mathbf{N}^{\circ} \\
\text { of } \\
\text { mice }\end{array}$ & Drug/Dose & Schedule/route & $\begin{array}{c}\text { BWV } \\
(\%)\end{array}$ & BLI (p/s/cm $\left.{ }^{2 /} \mathbf{s r}\right)$ & $\begin{array}{l}\text { TVI } \\
(\%)\end{array}$ \\
\hline \multirow{3}{*}{$\begin{array}{l}\text { MM473- } \\
\text { Luc }\end{array}$} & 10 & $\begin{array}{l}\text { Irinotecan } \\
20 \mathrm{mg} / \mathrm{kg}\end{array}$ & $\mathrm{q} 4 \mathrm{dx} 3 \mathrm{w} / \mathrm{IV}$ & - & $\begin{array}{c}1.96 \times 10^{6} \pm 2.82 \times 10^{6} \\
(+31)\end{array}$ & 37 \\
\hline & 8 & Vehicle & - & - & $\begin{array}{c}3.49 \times 10^{6} \pm 2.2 \times 10^{6} \\
(+40)\end{array}$ & - \\
\hline & 8 & $\begin{array}{c}\mathbf{1 b} \\
90 \mathrm{mg} / \mathrm{kg}\end{array}$ & $\mathrm{q} 4 \mathrm{~d} \times 3 \mathrm{w} / \mathrm{IV}$ & - & $\begin{array}{c}7.61 \times 10^{5} \pm 9.4 \times 10^{5} \\
(+40)\end{array}$ & 78 \\
\hline
\end{tabular}




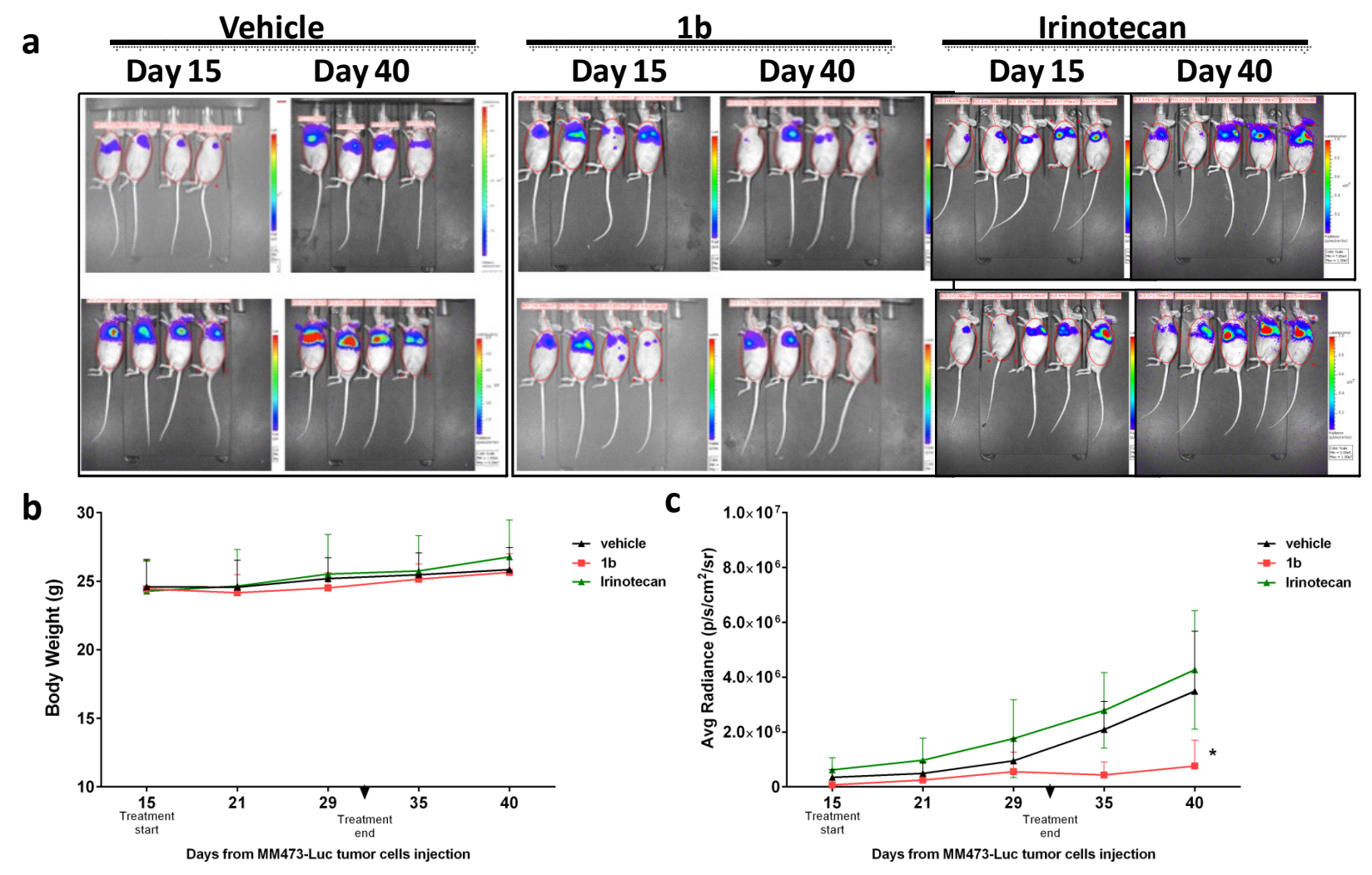

Fig.5. Efficacy of $\mathbf{1 b}$ in an orthotopic xenograft model of human epithelioid mesothelioma. a) bioluminescence signal of experimental groups observed at day 15 (when treatment started) and at day 40 (10 days after the last treatment); b) Body weight and c) tumor growth (expressed as Luciferase Average radiance) measurements throughout the experimental period. Statistical analysis performed using non parametric Mann-Whitney test (U) 1b group versus Vehicle $* \mathrm{p}<0,05$

\section{Conclusions}

Synergistic effects have been reported by co-treatment of various cancer cells with topoisomerase I and HDAC inhibitors. Based on a rational design method, camptothecin-psammaplin A hybrids were synthesized and evaluated. In particular, compound $\mathbf{1 b}$ displayed a broad spectrum of antiproliferative activity, with $\mathrm{IC}_{50}$ values in the nanomolar range, on a series of human solid tumor, hematologic and mesothelioma cell lines. Moreover, the compound showed a significant antitumor activity and very high tolerability in an in vivo human mesothelioma tumor model. Further work to develop analogues with optimized structure and improved bioactivity is ongoing.

\section{Experimental section}

\subsection{Chemistry}

All reagents and solvents were reagent grade or were purified by standard methods before use. Melting points were determined in open capillaries and are uncorrected. NMR spectra were 
recorded in $\mathrm{CDCl}_{3}$ (where not otherwise stated) at $300 \mathrm{MHz}$. Chemical shifts ( $\delta$ values) and coupling constants ( $\mathrm{J}$ values) are given in $\mathrm{ppm}$ and $\mathrm{Hz}$, respectively. Solvents were routinely distilled prior to use; anhydrous tetrahydrofuran (THF) and ether $\left(\mathrm{Et}_{2} \mathrm{O}\right)$ were obtained by distillation from sodium-benzophenone ketyl; dry methylene chloride was obtained by distillation from phosphorus pentoxide. All reactions requiring anhydrous conditions were performed under a positive nitrogen flow, and all glassware were oven dried and/or flame dried. Isolation and purification of the compounds were performed by flash column chromatography on silica gel 60 (230-400 mesh). Analytical thin-layer chromatography (TLC) was conducted on Fluka TLC plates (silica gel $60 \mathrm{~F}_{254}$, aluminum foil). Analyses indicated by the symbols of the elements or functions were within $\pm 0.4 \%$ of the theoretical values.

Compounds $\mathbf{4 a - b},{ }^{[28]} \mathbf{6 a - b},{ }^{[29]}$ 6-aminooxyhexanoic acid hydrobromide, ${ }^{[26]}$ and $\mathbf{2} \mathbf{a}-\mathbf{b}^{[25,27]}$ were prepared according to literature procedures.

\subsection{6-(camptothecin-7-yl(methyleneaminooxy)hexanoic acid $(\mathbf{3 a})$. To a solution of 7-} (dimethoxymethyl)camptothecin $\mathbf{2 a}(422 \mathrm{mg}, 1 \mathrm{mmol})$ in acetic acid (20 ml) 6-aminooxyhexanoic acid hydrobromide $\left(570 \mathrm{mg}, 2.5 \mathrm{mmol}\right.$ ) was added and the mixture heated $3 \mathrm{~h}$ at $80{ }^{\circ} \mathrm{C}$. The solvent was evaporated and the residue was purified by flash chromatography with $\mathrm{CH}_{2} \mathrm{Cl}_{2}: \mathrm{CH}_{3} \mathrm{OH}$ 93:7 to give $370 \mathrm{mg}$ of pure product (yield : $73 \%$ ). Mp: $132-133^{\circ} \mathrm{C} .{ }^{1} \mathrm{H}$ NMR (300 MHz, DMSO-d 6 ) $\delta$ : $9.29(1 \mathrm{H}, \mathrm{s}) ; 8.63-8.48(1 \mathrm{H}, \mathrm{m}) ; 8.29-8.10(1 \mathrm{H}, \mathrm{m}) ; 7.94-7.81(1 \mathrm{H}, \mathrm{m}) ; 7.80-7.65(1 \mathrm{H}, \mathrm{m}) ; 7.32(1 \mathrm{H}$, s); $6.55(1 \mathrm{H}, \mathrm{s}) ; 5.43(2 \mathrm{H}, \mathrm{s}) ; 5.27(2 \mathrm{H}, \mathrm{s}) ; 4.35(2 \mathrm{H}, \mathrm{t}, \mathrm{J}=7.0 \mathrm{~Hz}) ; 2.23-2.11(2 \mathrm{H}, \mathrm{m}) ; 1.98-1.72$ $(4 \mathrm{H}, \mathrm{m}) ; 1.66-1.52(2 \mathrm{H}, \mathrm{m}) ; 1.50-1.39(2 \mathrm{H}, \mathrm{m}) ; 0.89(3 \mathrm{H}, \mathrm{t}, \mathrm{J}=7.0 \mathrm{~Hz}) .{ }^{13} \mathrm{C} \mathrm{NMR}(300 \mathrm{MHz}$, DMSO-d6) $\delta: 174.9,172.9,157.0,152.8,150.3,149.0,145.5,145.1,131.5,130.8,130.2,128.6$, 127.2, 125.4, 124.6, 119.6, 97.1, 75.3, 72.8, 65.7, 52.6, 34.1, 30.7, 28.8, 25.4, 24.8, 8.24. ). Anal. calcd for $\mathrm{C}_{27} \mathrm{H}_{27} \mathrm{~N}_{3} \mathrm{O}_{7}$ : C, 64.15; H, 5.38; N, 8.31.Found: C, 63.80; H, 5.40; N, 8.29.

4.3. 6-(10-Hydroxycamptothecin-7-ylmethyleneaminooxy)hexanoic acid (3b). To a solution of 10hydroxy-7-formylcamptothecin $\mathbf{2 b}(294 \mathrm{mg}, 0.75 \mathrm{mmol})$ in ethanol (15 mL) 6-aminooxyhexanoic acid hydrobromide $(342 \mathrm{mg}, 1.5 \mathrm{mmol})$ and pyridine $(2.5 \mathrm{ml}, 30 \mathrm{mmol})$ were added and heated $4 \mathrm{~h}$ to reflux. The solvent was evaporated and dichloromethane $(20 \mathrm{ml})$ was added. The crude was heated to reflux for $1 \mathrm{~h}$. After cooling to rt, the solid was filtered. This treatment was repeated using $\mathrm{CH}_{2} \mathrm{Cl}_{2}$ : $\mathrm{CH}_{3} \mathrm{OH}$ 95:5 (20 ml) and $\mathrm{CH}_{2} \mathrm{Cl}_{2}: \mathrm{CH}_{3} \mathrm{OH}$ 99:1 $(20 \mathrm{ml})$ to give $287 \mathrm{mg}$ of product (yield: 75\%). ${ }^{1} \mathrm{H}-\mathrm{NMR}\left(300 \mathrm{MHz}, \mathrm{DMSO}-d_{6}\right) \delta: 10.53(1 \mathrm{H}, \mathrm{brs}) ; 10.38(1 \mathrm{H}, \mathrm{s}) ; 9.04(1 \mathrm{H}, \mathrm{s}) ; 8.70(1 \mathrm{H}$, brs); $8.08(1 \mathrm{H}, \mathrm{d}, \mathrm{J}=8.5 \mathrm{~Hz}) ; 7.74(1 \mathrm{H}, \mathrm{d}, \mathrm{J}=2.7 \mathrm{~Hz}) ; 7.50(1 \mathrm{H}, \mathrm{dd}, \mathrm{J}=8.5,2.7 \mathrm{~Hz}) ; 7.28(1 \mathrm{H}, \mathrm{s})$; $6.52(1 \mathrm{H}, \mathrm{s}) ; 5.43(2 \mathrm{H}, \mathrm{s}) ; 5.30(2 \mathrm{H}, \mathrm{s}) ; 4.41-4.27(2 \mathrm{H}, \mathrm{m}) ; 2.08-1.96(2 \mathrm{H}, \mathrm{m}) ; 1.95-1.73(4 \mathrm{H}, \mathrm{m})$; 
1.69-1.53 (2H, m); 1.52-1.38 (2H, m); $0.90(3 \mathrm{H}, \mathrm{t}, \mathrm{J}=7.0 \mathrm{~Hz}) .{ }^{13} \mathrm{C}-\mathrm{NMR}$ (DMSO-d $): \delta 174.8$, 172.9, 157.8, 157.0, 150.4, 149.4, 145.9, 144.9, 144.4, 131.9, 128.8, 127.6, 127.0, 123.2, 118.7, 105.7, 96.2, 75.1, 72.8, 65.7, 52.2, 34.1, 30.8, 28.8, 25.5, 24.8, 8.2. Anal. calcd for $\mathrm{C}_{27} \mathrm{H}_{27} \mathrm{~N}_{3} \mathrm{O}_{8}: \mathrm{C}$, C, 62.18; H, 5.22; N, 8.06.Found: 61.99; H, 5.23; N, 8.07.

4.4. 6-camptothecin-7-yl(methyleneaminooxy)hexanoic acid (2-\{2-[3-(4-hydroxyphenyl)-2hydroxyiminopropionylamino]ethyldisulfanyl\}ethyl)amide (1a).

To a solution of 3a $(50 \mathrm{mg}, 0.1 \mathrm{mmol})$ in dry DMF (5 ml) WSC (25 mg, $0.13 \mathrm{mmol})$ and HOBt (18 $\mathrm{mg}, 0.12 \mathrm{mmol})$ were added, the mixture was stirred $24 \mathrm{~h}$ at $\mathrm{rt}$, then $\mathbf{6 b}(80 \mathrm{mg}, 0.18 \mathrm{mmol})$ was added. The reaction was stirred $2 \mathrm{~h}$ at $\mathrm{rt}$. The solvent was evaporated and the residue was purified by flash chromatography with $\mathrm{CH}_{2} \mathrm{Cl}_{2}: \mathrm{CH}_{3} \mathrm{OH} 20: 1$ to give $60 \mathrm{mg}$ (yield: 74\%) of product. Mp: $108{ }^{\circ} \mathrm{C} .{ }^{1} \mathrm{H}-\mathrm{NMR}\left(300 \mathrm{MHz}, \mathrm{DMSO}-d_{6}\right) \delta: 9.31(1 \mathrm{H}, \mathrm{s}) ; 9.13(1 \mathrm{H}, \mathrm{brs}) ; 8.59(1 \mathrm{H}, \mathrm{d}, \mathrm{J}=8.6 \mathrm{~Hz})$; $8.21(1 \mathrm{H}, \mathrm{d}, \mathrm{J}=8.6 \mathrm{~Hz}) ; 8.05-7.83(3 \mathrm{H}, \mathrm{m}) ; 7.78-7.69(1 \mathrm{H}, \mathrm{m}) ; 7.34(1 \mathrm{H}, \mathrm{s}) ; 6.95(2 \mathrm{H}, \mathrm{d}, \mathrm{J}=8.4$ $\mathrm{Hz}) ; 6.59(2 \mathrm{H}, \mathrm{d}, \mathrm{J}=8.4 \mathrm{~Hz}) ; 6.52(1 \mathrm{H}, \mathrm{brs}) ; 5.42(2 \mathrm{H}, \mathrm{s}) ; 5.33(2 \mathrm{H}, \mathrm{s}) ; 4.33(2 \mathrm{H}, \mathrm{t}, \mathrm{J}=6.6 \mathrm{~Hz})$; 3.33-3.18 (4H., m); 2.84-2.62 (4H, m); 2.10 (2H, t, J = $7.3 \mathrm{~Hz}) ; 1.91-1.71(4 \mathrm{H}, \mathrm{m}) ; 1.65-1.50(2 \mathrm{H}$, $\mathrm{m}) ; 1.49-1.33$ (2H, m); 0.89 (3H, t, J = 7.1 Hz). ${ }^{13} \mathrm{C}-\mathrm{NMR}$ (DMSO-d6): 172.9, 172.6, 163.8, 157.1, 156.0, 152.7, 150.4, 149.1, 145.6, 145.2, 133.2, 131.7, 131.6, 130.9, 130.1(×2), 129.5, 129.2, 128.6, 127.2, 125.4, 119.6, $115.4(\times 2), 97.1,75.3,72.8,65.7,53.3,38.6,38.2,37.8,37.3,35.7,30.7,28.8$, 28.4, $25.5(\times 2)$, 8.2. Anal. calcd for $\mathrm{C}_{40} \mathrm{H}_{44} \mathrm{~N}_{6} \mathrm{O}_{9} \mathrm{~S}_{2}$ : C, 58.81; H, 5.43; N, 10.29. Found: 58.95; H, $5.41 ; \mathrm{N}, 10.31$.

4.5. Camptothecin-7-yl-methyleneaminooxy)hexanoic acid (2-\{2-[3-(3-bromo-4-hydroxyphenyl)-2hydroxyiminopropionylamino]-ethyldisulfanyl\}ethyl)amide (1b).

To a solution of 6-(camptothecin-7-ylmethyleneaminooxy)-hexanoic acid 3a (50 $\mathrm{mg}, 0.1 \mathrm{mmol})$ in dry DMF (5 ml) WSC (25 mg, $0.13 \mathrm{mmol})$ and HOBt $(18 \mathrm{mg}, 0.12 \mathrm{mmol})$ were added and the reaction was stirred $4 \mathrm{~h}$ at $\mathrm{rt}$, then $\mathbf{6 a}(85 \mathrm{mg}, 0.16 \mathrm{mmol})$ was added and the mixture was stirred $2 \mathrm{~h}$ at rt. The solvent was evaporated and the residue was purified by flash chromatography with $\mathrm{CH}_{2} \mathrm{Cl}_{2}: \mathrm{CH}_{3} \mathrm{OH}$ 10:1 to give $50 \mathrm{mg}$ (yield: $89 \%$ ) of compound 1b. Mp: $132{ }^{\circ} \mathrm{C}$. ${ }^{1} \mathrm{H}-\mathrm{NMR}(300$

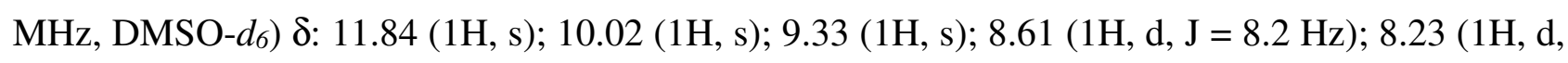
$\mathrm{J}=8.2 \mathrm{~Hz}) ; 8.13-8.03(1 \mathrm{H}, \mathrm{m}) ; 8.01-7.90(2 \mathrm{H}, \mathrm{m}) ; 7.82-7.71(1 \mathrm{H}, \mathrm{m}) ; 7.36(1 \mathrm{H}, \mathrm{s}) ; 7.26(1 \mathrm{H}, \mathrm{s})$; $6.99(1 \mathrm{H}, \mathrm{d}, \mathrm{J}=8.2 \mathrm{~Hz}) ; 6.81(1 \mathrm{H}, \mathrm{d}, \mathrm{J}=8.2 \mathrm{~Hz}) ; 6.54(1 \mathrm{H}, \mathrm{s}) ; 5.44(2 \mathrm{H}, \mathrm{s}) ; 5.35$ (2H, s); 4.40-4.30 $(2 \mathrm{H}, \mathrm{m}) ; 3.66(2 \mathrm{H}, \mathrm{s}) ; 2.85-2.64(4 \mathrm{H}, \mathrm{m}) ; 2.18-2.03(2 \mathrm{H}, \mathrm{m}) ; 1.96-1.72(4 \mathrm{H}, \mathrm{m}) ; 1.67-1.52(2 \mathrm{H}, \mathrm{m})$; 1.51-1.35 (2H, m); 1.30-1.14 (2H, m); 1.14-1.00 (2H, m); $0.88(3 \mathrm{H}, \mathrm{t}, \mathrm{J}=7.1 \mathrm{~Hz}) .{ }^{13} \mathrm{C} \mathrm{NMR}(75$ 
MHz, DMSO- $\left.d_{6}\right) \delta: 172.9,172.6,163.7(\times 2), 157.0,152.7,152.2,150.4,149.0,145.5,145.0$, 133.2, 131.5, 130.8, 130.2, 129.5, 129.2, 128.6, 127.1, 124.5, 125.3, 119.6, 116.5, 109.3, 97.1, 75.3, $72.8,65.7,52.6,38.6,38.2,37.9,37.3,35.7,30.8,28.8,28.1,25.5(\times 2), 8.2$. Anal. calcd for $\mathrm{C}_{40} \mathrm{H}_{43} \mathrm{BrN}_{6} \mathrm{O}_{9} \mathrm{~S}_{2}: \mathrm{C}, 53.63 ; \mathrm{H}, 4.84 ; \mathrm{N}, 9.38$;. Found: 53.75; H, 4.85; N, 9.36.

4.6. 10-Hydroxy-camptothecin-7-yl-methyleneaminooxy)-hexanoic acid (2-\{2-[3-(3-bromo-4hydroxyphenyl)-2-hydroxyiminopropionylamino]ethyldisulfanyl\}ethyl)amide (1c).

To a solution of $\mathbf{3 b}(30 \mathrm{mg}, 0.06 \mathrm{mmol})$ in dry DMF (5 ml) WSC (15 mg, $0.08 \mathrm{mmol})$ and $\mathrm{HOBt}$ (10 $\mathrm{mg}, 0.07 \mathrm{mmol}$ ) were added and the reaction was stirred $3 \mathrm{~h}$ at $\mathrm{rt}$, then compound $\mathbf{6 a}$ (47 $\mathrm{mg}$, $0.09 \mathrm{mmol}$ ) was added the mixture was stirred $2 \mathrm{~h}$ at $\mathrm{rt}$. The solvent was evaporated and the residue was purified by flash chromatography with $\mathrm{CH}_{2} \mathrm{Cl}_{2}: \mathrm{CH}_{3} \mathrm{OH}$ 10:1 give $30 \mathrm{mg}$ (yield: 57\%) of product. Mp: $138{ }^{\circ} \mathrm{C} .{ }^{1} \mathrm{H}-\mathrm{NMR}\left(300 \mathrm{MHz}, \mathrm{DMSO}-d_{6}\right) \delta: 11.84(1 \mathrm{H}, \mathrm{s}) ; 10.48(1 \mathrm{H}, \mathrm{s}) ; 10.02(1 \mathrm{H}$, s); $9.03(1 \mathrm{H}, \mathrm{s}) ; 8.15-7.82(3 \mathrm{H}, \mathrm{m}) ; 7.74(1 \mathrm{H}, \mathrm{s}) ; 7.54-7.40(1 \mathrm{H}, \mathrm{m}) ; 7.36-7.17(2 \mathrm{H}, \mathrm{m}) ; 7.04-6.90$ $(1 \mathrm{H}, \mathrm{m}) ; 6.90-6.75(1 \mathrm{H}, \mathrm{m}) ; 6.50(1 \mathrm{H}, \mathrm{s}) ; 5.42(2 \mathrm{H}, \mathrm{s}) ; 5.31(2 \mathrm{H}, \mathrm{s}) ; 4.40-4.22(2 \mathrm{H}, \mathrm{m}) ; 3.66(2 \mathrm{H}$, s); 2.97-2.65 (4H, m); 2.20-2.02 (2H, m); 1.94-1.68 (4H, m); 1.67-1.50 (2H, m); 1.50-1.36 (2H, m); 1.31-1.16 (2H, m); $0.87(3 \mathrm{H}, \mathrm{t}, \mathrm{J}=7.0 \mathrm{~Hz}) .{ }^{13} \mathrm{C}$ NMR (150 MHz, DMSO- $\left.d_{6}\right) \delta: 172.5,172.2,163.2$, $157.5,156.7,152.3,151.8,150.1,149.2$, 145.6, 144.8, 144.1, 132.8, 131.6, 129.1, 128.8, 128.6, 127.4, 126.7, 122.9, 188.2, 116.1, 108.8, 105.5, 95.8, 74.7, 72.4, 65.2, 51.9, 37.4, 36.8, 36.5, 35.2, 33.3, 30.2, 28.3, 27.7, $25.0(\times 2)$, 7.8. Anal. calcd for $\mathrm{C}_{40} \mathrm{H}_{43} \mathrm{BrN}_{6} \mathrm{O}_{10} \mathrm{~S}_{2}$ : C, 52.69; H, 4.75; N, 9.22; Found: 52.55; H, 4.76; N, 9.20.

\subsection{Cell lines}

Human primary epithelioid MM288 (ME-C001), MM317 (ME-C011), MM404 (ME-C021), MM473 (ME-C051), MM481 (ME-C061); biphasic MM487 (MB-C071) and MM491 (MB-C081); sarcomatoid MM432 (MS-C031) and MM472 (MS-C041) mesothelioma cell lines.

Human K562 erythromyeloblastoid leukemia (ATCC \# CCL-243), ARH-77 plasma leukemia (ATCC \# CRL-1621), THP1 and MV4-11 monocytic leukemia (ATCC \# TIB-202, CRL-9591), Jurkat acute T-cell leukemia (ECACC \# 90112119), U937 histiocytic lymphoma (ATCC \# CRL1593), RAJI, DG-75, and RAMOS Burkitt lymphoma (DSMZ \# ACC-319, ACC-83, ACC-603); MAVER, MINO, REC-1 (DSMZ \# ACC-717, ACC-687, ACC-584), JECO-1, Z-138 (ATCC \# CRL-3006, CRL-3001) mantle cell lymphoma; KM-H2 and L-428 Hodgkin lymphoma (DSMZ \# ACC-8, ACC-197), OCI-LY3 and U-2932 diffuse large B-cell lymphoma (DSMZ \# ACC-731, ACC-633), RPMI-8226 and NCI-H929 multiple myeloma (ATCC \# CCL-155, CRL-9068). 
Human NCI-H460 NSCLC (ATCC \# HTB-177), Capan-1 pancreatic carcinoma (ATCC \# HTB79), A431 epidermoid carcinoma (ATCC \# CRL-1555), HeLa cervix carcinoma (ATCC \# CCL-2), A2780 and A2780-Dx multidrug-resistant ovarian carcinoma (ECACC \# 93112519, 93112520), HT29 colorectal carcinoma (ECACC \# 91072201), HepG2 hepatocellular carcinoma (ATCC \# HB8065), DU145 prostate carcinoma (ATCC \# HTB-81).

\subsection{Cell cultures}

All mesothelioma cell lines were cultured in F-10 Nutrient Mixture medium supplemented with $10 \%$ Foetal Bovine Serum (FBS), 2 mM L-glutamine and gentamicin sulfate.

NCI-H60, A2780, A2780-Dx, HeLa, U937, RPMI-8226, ARH-77, Jurkat, RAJI, REC-1, DG-75, U2932, KM-H2 and L-428 cells were cultured in RPMI-1640 medium supplemented with $10 \%$ FBS, 2 mM L-glutamine and gentamicin sulfate. RAMOS, OCI-LY3, JECO-1, MAVER-2, MINO cells were cultured in RPMI-1640 medium supplemented with $20 \%$ FBS, 2 mM L-glutamine and gentamicin sulfate. THP1 and H929 cells were cultured in RPMI-1640 medium supplemented with $10 \%$ FBS, 0.05 mM mercaptoethanol, L-glutamine and gentamicin sulfate. K562, MV4-11, Z-138 cells were cultured in IMDM medium supplemented with $10 \%$ FBS, L-glutamine and gentamicin sulfate. Capan-1 cells were cultured in IMDM medium supplemented with $10 \%$ FBS, 2 mM Lglutamine and gentamicin sulfate. A431, DU145, and HepG2 cells were cultured in EMEM medium supplemented with $10 \%$ FBS, 2 mM L-glutamine and gentamicin sulfate. HT29 cells were cultured in McCoy's medium supplemented with $10 \%$ FBS, 2 mM L-glutamine and gentamicin sulfate.

Cells were maintained in an incubator at $37^{\circ} \mathrm{C}$ with saturated humidity and an atmosphere of $95 \%$ air and $5 \% \mathrm{CO}_{2}$, and were sub-cultured every 2-3 days.

\subsection{Cytotoxicity assay}

Human tumor cells were seeded in 96-wells plastic plates, allowed to attach, and exposed to scalar concentrations of the drug compounds. Cell survival was evaluated upon $72 \mathrm{~h}$ by the sulphorhodamine B (SRB) or MTT assay and the $\mathrm{IC}_{50}$ value (drug concentration inhibiting $50 \%$ of cell growth) calculated by the ALLFIT program.

\subsection{HDAC's profiling}

The experiments were carried out in RBC facility (http://www.reactionbiology.com/) by using in triplicate 10 concentrations of each compound starting from $10 \mu \mathrm{M}$. The substrate for HDAC 1, 2, 6 , and 10 was Fluorogenic peptide from p53 residues 379-382 (RHKK(Ac)AMC). The Substrate for HDAC4 was Fluorogenic HDAC Class2a Substrate (Trifluoroacetyllysine) IC $_{50}$ values were calculated using the GraphPad Prism 4 program based on a sigmoidal dose-response equation. 
No reducing agent was added to the test system.

\subsection{Protein analysis}

Exponentially growing mesothelioma cells (MM473) were collected in Dulbecco's 1x PBS buffer and lysed in RIPA lysis buffer (50mM Tris-HCl, $150 \mathrm{mM} \mathrm{NaCl}, 0,5 \%$ Na-Deoxycholate, 1\% NP-40, $0.15 \%$ SDS) containing protease and phosphatase inhibitors and then centrifuged at $12000 \mathrm{rpm}$ for 10 minutes at $4{ }^{\circ} \mathrm{C}$. The supernatants, containing the total proteins extracts, were transferred in new vials. The protein concentration was measured by Bradford Protein Assay. Equal amounts of proteins for each sample were then resolved by SDS-PAGE and loaded on 10-12\% polyacrilamide gels. The proteins were then transferred on nitrocellulose membranes. Molecular weights were estimated based upon the relative migration with molecular weight protein markers. The nonspecific binding were blocked by incubation of membranes in TBS-tween (25 mM Tris, $150 \mathrm{mM}$ $\mathrm{NaCl}, 0.1 \%$ Tween 20) with 5\% nonfat dry milk (BIORAD, Milan) for 60 minutes. Subsequently, the membranes were incubated overnight with primary antibodies: anti-Histone H4 (Millipore, 1:500), anti-acetyl-H4 (Santa Cruz, 1:1000) anti-p21 (Santa Cruz, 1:1000), anti-acetyl-tubulin (abcam, 1:1000), anti- $\alpha$-tubulin (Sigma, 1:5000), anti $\beta$-actin (Sigma, 1:5000) and antiTopoisomerase 1 (Santa Cruz, 1:500). After three washes with TBST blots were incubated with HRP-conjugated secondary anti-mouse and anti-rabbit antibodies (Santa Cruz, 1:5000) 1 hour at room temperature. After three washes with TBST the blots were developed with ECL substrate (GE Healthcare) and chemiluminescence detected by ChemiDoc Imaging System (Biorad). The optical density of the protein bands detected by western blotting was normalized on $\alpha$-tubulin levels and analyzed by ChemiDoc software (Biorad).

\subsection{In vivo antitumor activity}

MM473 cells were cultured in Ham's F-10 Nutrient Mixture supplemented with $10 \%$ FBS, 2 mM L-glutamine, and G418 antibiotic and expanded in a $37{ }^{\circ} \mathrm{C}$ incubator with saturated humidity and an atmosphere of $95 \%$ air and $5 \% \mathrm{CO}_{2}$, and were sub-cultured every 2-3 days. Before the injection in mice, cells were checked with MycoAlert ${ }^{\circledR}$ Mycoplasma Detection Kit (Lonza) to exclude mycoplasma contamination, counted by trypan blue dye exclusion, evaluated for cell viability (> 95\%). Human epithelioid mesothelioma cell lines (MM473) were expanded and re-suspended at the concentration of $1 \times 10^{7} / \mathrm{ml}$ in M199. Tumor cells were orthotopically inoculated intrapleurally (i.pl.) in CD-1 nude mice (Charles River) at concentration of $1 \times 10^{6} / 200 \mu 1$ M199/mouse. Compound 1b was diluted in 10\% 1:1 Absolute Ethanol-Cremophor solution in saline. 1b was administered i.v at $90 \mathrm{mg} / \mathrm{kg}$ using a q4dx3w schedule. Irinotecan was administered iv at $20 \mathrm{mg} / \mathrm{kg}$, using the schedule 
$\mathrm{q} 4 \mathrm{dx} 3 \mathrm{w}$. Tumor growth was evaluated weekly by using the IVIS Spectrum (PerkinElmer) in vivo technology system, through intraperitoneal injection of D-Luciferin (100 $\mu \mathrm{L} / 10 \mathrm{gr}$, PerkinElmer). For each animal the specific average radiance signal was evaluated. Ethics approval was obtained from the Italian Ministry of Health and all experiments were in accordance with the European guidelines for the care and use of laboratory animals.

\subsection{Statistical analysis}

Statistical analysis was performed by using U-Test (GraphPad Prism 6). Outliers were removed by using the Rout test $(\mathrm{Q}=10 \%$, GraphPad Prism 6).

\subsection{Molecular Modeling}

The ligand molecules were refined using a systematic conformer search followed by geometry optimisation of the lowest energy structure with MOPAC7 (PM3 Method, RMS gradient 0.0100). The DNA-Topoisomerase-I and HDAC-II models were derived from the deposited X-ray structures (Protein Data Bank entry 1T8I and 5IWG, respectively).

Energy minimisations and molecular modeling calculations were performed by using the CUDA® version of the GROMACS package [32] and the AMBER-03 [33] force field, a variant of the AMBER-99 [-34] potential in which charges and main-chain torsion potentials have been derived based on QM+continuum solvent calculations and each amino acid is allowed unique main-chain charges (nucleic acids have not been modified from AMBER-99).

Molecular docking experiments were performed with Autodock 4.0 [35]. We used the Lamarckian Genetic Algorithm which combines global search (Genetic Algorithm alone) to local search (Solis and Wets algorithm) [36]. Ligands and receptors were further processed using the Autodock Tool Kit (ADT) [37]. Gasteiger-Marsili charges [38] were loaded on the ligands in ADT and Cornell parameters were used for the phosphorous atoms in the DNA. Solvation parameters were added to the final structure using the Addsol utility of Autodock. Each docking consisted of an initial population of 100 randomly placed individuals, a maximum number of 200 energy evaluations, a mutation rate of 0.02 , a crossover rate of 0.80 , and an elitism value of 1 . For the local search, the socalled pseudo-Solis and Wets algorithm was applied using a maximum of 250 iterations per local search. 250 independent docking runs were carried out for each ligand. The grid maps representing the system in the actual docking process were calculated with Autogrid. The dimensions of the grids were $80 \times 80 \times 80$, with a spacing of $0.1 \AA$ between the grid points and the center close to the cavity left by the ligand after its removal. The simpler inter-molecular energy function based on the Weiner force field in Autodock was used to score the docking results. Results differing by less than 
1.0 $\AA$ in positional root-mean-square deviation ( $\mathrm{rmsd}$ ) were clustered together and were represented by the result with the most favourable free energy of binding. The poses were equilibrated by a 5.0 ns molecular dynamics simulation using the CUDA® version of the GROMACS package.

\section{Acknowledgments}

The authors gratefully acknowledge Prof. Lucio Merlini and Dr. Alberto Bargiotti for helpful suggestions and discussions.

\section{Appendix A. Supplementary data}

Supplementary data related to this article can be found at

\section{References}

1. N. Ma , Y. Luo , Y. Wang, C. Liao, W. C. Ye, S. Jiang, Curr. Top Med. Chem. 16 (2016) 415-26.

2. A. Ganesan, Macrocyclic Inhibitors of Zinc-dependent Histone Deacetylases (HDACs), in: J. Levin (Ed) Macrocycles in Drug Discovery; RSC, Cambridge, 2015; pp.109-140.

3. E. Quiñoa`, P. Crews, Tetrahedron Lett. 28 (1987) 3229-3232.

4. L. Arabshahi, F. J. Schmitz, J. Org. Chem. 52 (1987) 3584-3586.

5. A. D. Rodriguez, R. K. Akee, P. J. Scheuer, Tetrahedron Lett. 28 (1987) 4989-4992.

6. I. C. Piña, J. T. Gautschi, G. Y. S. Wang, M. L. Sanders, F. J. Schmitz, D. France, S. Cornell-Kennon, L. C. Sambucetti, S. W. Remiszewski, L. B. Perez, K. W. Bair, P. Crews, J. Org. Chem. 68 (2003)3866-3873.

7. M. G. J. Baud, T. Leiser, V. Petrucci, M. Gunaratnam, S. Neidle, F. J. Meyer-Almes, M. J. Fuchter Beilstein J. Org. Chem. 9 (2013) 81-88.

8. Q. Yang, D. Liu, D. Sun, S. Yang, G. Hu, Z. Wu, L. Zhao, Molecules 15 (2010) 8784-8795.

9. S. Hong, Y. Shin, M. Jung, M. W. Ha, Y. Park, Y. -J Lee, J. Shin, K. B. Oh, S. K. Lee, H. Park, Eur. J. Med. Chem. 96 (2015) 218-230.

10. L. Musso, S. Dallavalle, F. Zunino, Biochem. Pharmacol. 96 (2015) 297-305.

11. G. Berube, G. Expert Opinion Drug Discov. 11 (2016) 281-305.

12. R. Cincinelli, L. Musso, S. Dallavalle, R. Artali, S. Tinelli, D. Colangelo, F. Zunino, M. De Cesare, G. L. Beretta, N. Zaffaroni, Eur. J. Med. Chem 63 (2013) 387-400. 
13. Y. -Q. Liu, W. -Q. Li, S. L. Morris-Natschke, K. Qian, L. Yang, G. -X. Zhu, X. -B. Wu, A. -L. Chen, S. -Y. Zhang, X. Nan, K. -H. Lee, Med. Res. Rev. 35 (2015) 753-789.

14. E. Martino, S. Della Volpe, E. Terribile, E. Benetti, M. Sakaj, A. Centamore, A. Sala, S. Collina, Bioorg. Med. Chem. Lett. 27 (2017) 701-707.

15. F. Bruzzese, M. Rocco, S. Castelli, E. Di Gennaro, A. Desideri, A. Budillon, Mol Cancer Ther. 8 (2009) 3075-3087.

16. B. Sarcar, S. Kahali, P. Chinnaiyan, J Neurooncol. 99 (2010) 201-207.

17. A. Sato, T. Asano, A. Horiguchi, K. Ito, M. Sumitomo, T. Asano, Oncol Res. 19 (2011) 217223.

18. J. Gray, C. L. Cubitt, S. Zhang, A. Chiappori, Cancer Biol. Ther. 13 (2012), 614-622.

19. M. Ocker, A. Alajati, M. Ganslmayer, S. Zopf, M. Lueders, D. Neureiter, E. G. Hahn, D. Schuppan, C. Herold, J. Cancer Res. Clin. Oncology 131 (2005), 385-394.

20. Y. S. Na, S. M. Kim, K. A. Jung, S. Y. Yang, Y. S. Hong, M. H. Ryu, S. Ro, D. H. Cho, J. C. Kim, D. H. Jin, J. S. Lee, T. W. Kim TW. Oncol Rep. 24 (2010) 1509-1514.

21. G. Guerrant, V. Patil, J.C. Canzoneri, L.P. Yao, R. Hood, A.K. Oyelere, Bioorg. Med. Chem.Lett. 23 (2013) 3283-3287.

22. C. Pisano, M. De Cesare, G. L. Beretta, V. Zuco, G. Pratesi, S. Penco, L. Vesci, F. F. Foderà, M. B. Guglielmi, P. Carminati, S. Dallavalle, G. Morini, L. Merlini, A. Orlandi, F. Zunino, Mol. Cancer Ther. 7 (2008) 2051-2059.

23. S. Dallavalle, A. Ferrari, L. Merlini, S. Penco, N. Carenini, P. Perego, F. Zunino, Bioorg. Med. Chem. Lett. 11 (2001) 291-294.

24. M. De Cesare, G. L. Beretta, S. Tinelli, V. Benedetti, G. Pratesi, S. Penco, S. Dallavalle, L. Merlini, C. Pisano, P. Carminati, F. Zunino, Biochem. Pharmacol. 73 (2007) 656-664.

25. G. Giannini, M. Marzi, W. Cabri, E. Marastoni, G. Battistuzzi, L. Vesci, C. Pisano, G. L. Beretta, M. De Cesare, F. Zunino, Bioorg. Med. Chem. Lett. 2008, 18, 2910-2915.

26. J. Peuralahti, K. Puukka, H. Hakala, V.-M. Mukkala, O. Mulari, P. Hurskainen, J. Hovinen Bioconjugate Chem. 13 (2002) 876-880.

27. S. Dallavalle, T. Delsoldato, A. Ferrari, L. Merlini, S. Penco, N. Carenini, P. Perego, M. De Cesare, G. Pratesi, F. Zunino, J. Med. Chem. 43 (2000) 3963-3969. 
28. A. M. Godert, N. Angelino, A.Woloszynska-Read, S. R. Morey, S. R. James, A. R. Karpf, J. R. Sufrin, Bioorg. Med. Chem. Lett. 16 (2006) 3330-3333.

29. F. Hentschel, F. Sasse, T. Lindel, Org. Biomol. Chem. 10 (2012) 7120-7133.

30. D. H. Kim, J. Shin, H. J. Kwon, Exp. Mol. Med. 39 (2007) 47-55.

31. M. G. J. Baud, T. Leiser, P. Haus, S. Samlal, A. C. Wong, R. J. Wood, V. Petrucci, M. Gunaratnam, S. M. Hughes, L. Buluwela, F. Turlais, S. Neidle, F-J. Meyer-Almes, A. J. P. White, M. J. Fuchter J. Med. Chem. 55 (2012) 1731-1750.

32. E. Lindahj, B. Hess, D. van der Spoel, Mol. Model. Annu. 7 (2001) 306-317.]

33. Y, Duan, C. Wu, S. Chowdhury, M. C. Lee, G. Xiong, W. Zhang, R. Yang, P. Cieplak, R. Luo, T. Lee, J. Caldwell, J. Wang, P. Kollman, J. Comp. Chem. 24 (2003), 1999-2012.

34. J. Wang, P. Cieplak, P. A. Kollman, J. Comp. Chem. 21 (2000) 1049-1074.

35. R. Huey, G.M. Morris, A.J. Olson, D.S.S. Goodsell, J. Comput. Chem. 28 (2007) 11451152.

36. F.J. Solis, R.J.B. Wets, Math. Oper. Res. 6 (1981) 19-30.

37. M.F. Sanner, J. Mol. Graph. Model. 17 (1999) 57-61.

38. J. Gasteiger, M.M. Marsili, Tetrahedron 36 (2008) 3219-3228. 